\title{
Public health implications of an outbreak of rabies in arctic foxes and reindeer in the Svalbard archipelago, Norway, September 2011
}

E MacDonald (Emily.MacDonald@fhi.no) ${ }^{1}$, K Handeland ${ }^{2}$, H Blystad ${ }^{1}$, M Bergsaker $^{1}$, M Fladberg ${ }^{1}$, B Gjerset $^{2}$, O Nilsen $^{1}$, H Os $^{3}$, S Sandbu ${ }^{1}$, E Stokke ${ }^{4}$, L Vold ${ }^{1}$, I Ørpetveit ${ }^{2}$, H Gaup Åmot ${ }^{3}$, O Tveiten ${ }^{5}$

1. Norwegian Institute of Public Health (Nasjonalt Folkehelseinstitutt), Oslo, Norway

2. Norwegian Veterinary Institute (Veterinærinstituttet), Oslo, Norway

3. Norwegian Food Safety Authority (Mattilsynet), Oslo, Norway

4. The Governor of Svalbard (Sysselmannen), Longyearbyen, Svalbard, Norway

5. Longyearbyen hospital, Longyearbyen, Svalbard, Norway

Citation style for this article:

MacDonald E, Handeland K, Blystad H, Bergsaker M, Fladberg M, Gjerset B, Nilsen O, Os H, Sandbu S, Stokke E, Vold L, Ørpetveit I, Gaup Åmot H, Tveiten O. Public health implications of an outbreak of rabies in arctic foxes and reindeer in the Svalbard archipelago, Norway, September 2011

Euro Surveill. 2011;16(40):pii=19985. Available online: http://www.eurosurveillance.org/ViewArticle.aspx?Articleld=19985

Between 16 September and 5 October 2011 rabies was diagnosed in two arctic foxes and eight reindeer in the Svalbard archipelago, in Norway. This outbreak occurs at the end of the reindeer hunting season and poses an increased risk to many people that were involved in the hunt. As of 28 September 2011, 280 people had received post-exposure prophylaxis. No human cases of rabies have occurred.

On 12 September 2011 an arctic fox (Vulpes lagopus) attacked a woman in Longyearbyen (Norway), a city with a population of approximately 2,000 inhabitants in the Svalbard archipelago in the Arctic. Later on the same day, a dog killed presumably the same fox. According to the tests performed by the Norwegian Veterinary Institute, this fox tested positive for rabies. In the two days following the event, the dog had contact with four people, including licking their hands and faces. On 18 September, two reindeer (Rangifer tarandus platyrhynchus) exhibiting unusual behaviour were found on the outskirts of Longyearbyen. Both were shot and, after testing by the Norwegian Veterinary Institute, were found to be positive for the rabies virus. The carcasses of three more reindeer found on 26 September more than $100 \mathrm{~km}$ south of Longyearbyen (Hornsund) have tested positive for rabies. Three additional reindeer and a second fox found between 25 September and 30 September on the outskirts of Longyearbyen also subsequently tested positive for rabies (Table 1).

\section{Potential exposure of local population}

The archipelago of Svalbard has a population of 2,539 with most people living in the city of Longyearbyen. Svalbard has a substantial multi-national population including 425 Russian and Ukrainian citizens living in the mining community of Barentsburg and many workers and researchers from other countries working in the archipelago. This outbreak occurs at the end of the reindeer hunting season in the Svalbard archipelago which lasts from 15 August to 20 September. Between 200 and 300 hunters participated in the hunt in which approximately 200 reindeer were killed. Although most participants are residents of Svalbard, visitors from outside the archipelago were also involved in the hunt. The Governor's office maintains a list of all participants. Groups of children from daycares and schools also participated in the hunt and in several cases were allowed to touch the animals after they were shot.

For hunting control and routine animal population surveillance purposes, hunters are asked to separate the mandible from the reindeer carcass and send it to the Svalbard Governor's office. This procedure may involve exposure to the animal's oral cavity, saliva and spinal

\section{TABLE 1}

Animals testing positive for rabies during the outbreak in the archipelago of Svalbard, Norway, as of 5 October 2011

\begin{tabular}{|l|c|c|c|}
\hline Type of animal & Location & $\begin{array}{c}\text { Date when the } \\
\text { animal was } \\
\text { found }\end{array}$ & $\begin{array}{c}\text { Date of } \\
\text { positive test } \\
\text { results }\end{array}$ \\
\hline Fox & Longyearbyen $^{12 \mathrm{Sep}}$ & 16 Sep \\
\hline Reindeer & Fuglefjellet $^{\mathrm{a}}$ & $18 \mathrm{Sep}$ & $21 \mathrm{Sep}$ \\
\hline Reindeer & Platåberget $^{\mathrm{a}}$ & $18 \mathrm{Sep}$ & $21 \mathrm{Sep}$ \\
\hline Reindeer & Platåberget $^{\mathrm{a}}$ & $25 \mathrm{Sep}$ & $28 \mathrm{Sep}$ \\
\hline Reindeer & Hornsund $^{\mathrm{b}}$ & $26 \mathrm{Sep}$ & 30 Sep \\
\hline Reindeer & Hornsund $^{\mathrm{b}}$ & $26 \mathrm{Sep}$ & 30 Sep \\
\hline Reindeer & Hornsund $^{\mathrm{b}}$ & $26 \mathrm{Sep}$ & $30 \mathrm{Sep}$ \\
\hline Fox & Bjørndalen $^{\mathrm{a}}$ & $28 \mathrm{Sep}$ & 3 Oct \\
\hline Reindeer & Fuglefjellet $^{\mathrm{a}}$ & $30 \mathrm{Sep}$ & 5 Oct \\
\hline Reindeer & Fuglefjellet $^{\mathrm{a}}$ & $30 \mathrm{Sep}$ & 5 Oct \\
\hline
\end{tabular}

a On the outskirts of Longyearbyen.

b More than $100 \mathrm{~km}$ south of Longyearbyen. 
cord (while cutting off the head of the carcass). At the time the rabies virus was detected on 21 September in the first two reindeer, many people had already consumed cooked reindeer meat obtained during the hunting period and many still have meat in their freezers.

\section{Rabies in the Arctic}

Rabies is considered an endemic disease throughout most parts of the Arctic. Outbreaks of rabies have been previously reported in Canada, Russia and Greenland [1]. Rabies was first diagnosed in Svalbard in 1980 with an outbreak in the fox population [2]. From 1980 to 1999, a total of 25 animals were diagnosed with rabies on the islands of the archipelago, including three reindeer. While there is not a systematic surveillance system for rabies in place, there is significant concern among both officials and residents of Svalbard for the limited wildlife population. Animals exhibiting unusual behaviour or found dead for unknown reasons are routinely autopsied. In particular, all foxes found dead are autopsied. No further cases were reported until January 2011, when an arctic fox attacked a group of dogs at a meteorological station on Hopen, an island in the south-eastern part of the Svalbard archipelago [3]. Mainland Norway continues to be free of rabies. No human cases of rabies have occurred in Norway.

\section{Transmission of rabies}

The arctic fox is the main host of the virus, although how rabies is maintained in the relatively low-density fox population is unknown. Long incubation periods, prolonged periods of virus excretion and oral infection through frozen carcasses have been proposed as possible explanations [1]. The rabies virus is concentrated in the central nervous system (CNS) and is excreted through the salivary glands of rabid animals [4]. Animals can also excrete the virus through the saliva during a restricted period of time before any signs of disease occur [5]. The primary mode of transmission to humans is through the saliva in a bite from an infected animal. Rabies has also been transmitted, albeit rarely, via contamination of mucous membranes (i.e. eyes, nose, mouth), inhalation of virus-containing aerosol or via transplantation of an infected organ [6]. There may also be a limited risk that a dog that has bitten or eaten an animal infected with rabies may be able to temporarily retain the virus in its mouth and transmit it by biting or licking a person with scratches or wounds. The rabies virus is not transmitted through blood, faeces or urine. There is only negligible evidence that consumption of properly cooked meat from rabies-infected animals poses any risk for transmission of the disease and the World Health Organization reports that ingestion of raw meat is not a known source of human infection [7]. However, there may be limited risk of transmission associated with handling meat prior to cooking if one is in contact with the CNS, salivary glands or saliva, or if cross contamination from the CNS, salivary glands or saliva has occurred during the butchering process [8]. This is primarily a concern if the person handling the meat has cuts or scratches on the hands. While freezing does not kill the rabies virus, it is inactivated by exposure to sunlight and at temperatures above $56^{\circ} \mathrm{C}[9]$.

\section{Post-exposure prophylaxis recommendations}

Concern regarding the possible human exposure to rabies through the dog initiated a public health response by the hospital in Longyearbyen in conjunction with the Norwegian Institute of Public Health (NIPH), which was later expanded to include those involved in the reindeer hunt. At the time the rabies virus was detected in the two reindeer, many people were concerned because they had already consumed reindeer meat obtained during the hunting period and were unsure as to whether this posed a risk requiring post-exposure prophylaxis. The NIPH has issued recommendations on who should receive post-exposure prophylaxis based on different exposures, which are presented in Table 2.

The reindeer hunters who have been involved in removing the mandible of the reindeer (or have in other ways been in direct contact with saliva, the oral cavity or the central nervous system of a reindeer) fall under Group

\section{TABLE 2}

Post-exposure prophylaxis recommendations following the outbreak of rabies in the archipelago of Svalbard, Norway, September 2011

\begin{tabular}{|c|c|c|}
\hline Exposure risk groups & Unvaccinated & Vaccinated \\
\hline \multicolumn{3}{|l|}{ Group 1} \\
\hline $\begin{array}{l}\text { Individuals who have been bitten, scratched or cut through contact with animals } \\
\text { suspected to be infected with rabies }\end{array}$ & $\begin{array}{l}\text { Rabies immunoglobulin } \\
+5 \text { vaccine doses } \\
\text { (Days } 0,3,7,14 \text { and } 30 \text { ) }\end{array}$ & $\begin{array}{l}2 \text { vaccine doses } \\
\text { (Days o and 3) }\end{array}$ \\
\hline \multicolumn{3}{|l|}{ Group 2} \\
\hline $\begin{array}{l}\text { Individuals who have been licked or bitten by a dog that has had direct contact within } \\
\text { the previous two days with another animal suspected to be infected with rabies }\end{array}$ & $\begin{array}{l}5 \text { vaccine doses } \\
\text { (Days } 0,3,7,14 \text { and } 30)\end{array}$ & $\begin{array}{l}2 \text { vaccine doses } \\
\text { (Days o and 3) }\end{array}$ \\
\hline \multicolumn{3}{|l|}{ Group 3} \\
\hline $\begin{array}{l}\text { Individuals who have had direct contact with saliva, the oral cavity or the central } \\
\text { nervous system of a reindeer (e.g. when removing the jaw of the animal) }\end{array}$ & $\begin{array}{l}5 \text { vaccine doses } \\
\text { (Days } 0,3,7,14 \text { and } 30)\end{array}$ & $\begin{array}{l}2 \text { vaccine doses } \\
\text { (Days o and 3) }\end{array}$ \\
\hline
\end{tabular}

Source: Norwegian Institute of Public Health (Nasjonalt Folkehelseinstitutt). 
3 and have been offered post-exposure prophylaxis. The Norwegian Food Safety Authority has, in collaboration with the NIPH and the Norwegian Veterinary Institute, issued advice that the consumption of well cooked reindeer meat does not present any health hazard with respect to rabies. The public is advised not to consume the brain or the spinal cord.

Since rabies has been observed on the islands for many years, vaccination of all dogs in the Svalbard archipelago was required before the outbreak. Dogs that have had contact with suspected rabid animals should be kept isolated in line with the World Organisation for Animal Health (OIE) recommendations and receive a booster vaccine. People who had been licked by the dog in the two days after it had killed the fox were recommended post-exposure prophylaxis.

\section{Measures implemented}

The Vaccine Department at NIPH has sent out approximately 1,100 doses of the rabies vaccine and 10 treatments of immunoglobulin against rabies in response to the Svalbard situation. These shipments have mainly been sent to the Svalbard archipelago although some have also been sent to parts of mainland Norway for people who have already left Svalbard. On Svalbard, vaccination is being organised by the local health authorities and administered at the hospital in Longyearbyen. Vaccination clinics are being simultaneously held at the school in Longyearbyen. The vaccine is also being made available in the settlement of $\mathrm{New}$ Ålesund, in the north-eastern part of the archipelago of Svalbard, in Barentsburg and to hunters located in other places on the island through helicopter transport. As of 28 September, only one person belonging to Group 1 has been identified and has received immunoglobulin in addition to vaccines as post-exposure prophylaxis. Four individuals belonging to Group 2 received postexposure prophylaxis after having had contact with the dog that killed the rabid fox. People belonging to Group $3(n=275)$ have received post-exposure prophylaxis; most of these individuals were involved in reindeer hunting. Although the Governor's office maintains a list of those involved in the hunt, most individuals have independently sought post-exposure prophylaxis. Despite the standing recommendation that hunters

\section{TABLE 3}

Post-exposure prophylaxis given following the outbreak of rabies in the archipelago of Svalbard, Norway, as of 28 September $2011(n=280)$

\begin{tabular}{|l|c|}
\hline Exposure risk groups $^{\mathrm{a}}$ & $\begin{array}{c}\text { Number of people who received } \\
\text { post-exposure prophylaxis }\end{array}$ \\
\hline Group 1 & 1 \\
\hline Group 2 & 4 \\
\hline Group 3 & $\mathbf{2 7 5}$ \\
\hline Total & $\mathbf{2 8 0}$ \\
\hline
\end{tabular}

a As described in Table 2. should be vaccinated against rabies, almost nobody receiving post-exposure prophylaxis had been previously vaccinated.

The dog that killed the rabid fox was vaccinated prior to the incident but has been placed in isolation for a period of 45 days in line with OIE recommendations as a precautionary measure. At present there are no indications that the dog may be infected with rabies.

In conjunction with the Norwegian Food Safety Authority, the Governor of Svalbard has urged the public to avoid contact with dead animals or animals exhibiting unusual behaviour.

Arctic foxes found in the city of Longyearbyen will be caught and killed by the authorities. Regular surveillance of the outskirts of Longyearbyen by helicopter for dead or sick animals is being performed. Fox traps have been set up in Longyearbyen as a measure to reduce the fox population in the area. In addition to being vaccinated against rabies, dogs must now be kept leashed or fenced in and under surveillance at all times. The public has been asked to notify the Governor's office of any animal carcasses or animals exhibiting unusual behaviour. Information is being provided to residents of Svalbard in Norwegian, English and Russian. Although the situation does not warrant travel advisories, for many years the NIPH has recommended that residents and visitors to the Svalbard archipelago likely to be in contact with wild animals (such as hunters, scientists and wildlife explorer) should receive the rabies vaccine.

\section{Conclusion}

Reindeer hunting is a popular activity that annually involves up to 300 people, including children. The rabies outbreak in the Svalbard archipelago has demonstrated that people engaging in activities involving contact with wild animals in rabies-endemic areas should consider being vaccinated. The recent events have had a significant public health impact on the residents of Svalbard, in particular for those involved in reindeer hunting.

References

1. Mørk T, Prestrud P. Arctic rabies--a review. Acta Vet Scand. 2004;45(1-2):1-9.

2. Odegaard OA, Krogsrud J. Rabies in Svalbard: infection diagnosed in arctic fox, reindeer and seal. Vet Rec. 1981;109(7): 141-2.

3. Ørpetveit I, Ytrehus B, Vikøren T, Handeland K, Mjøs A, Nissen S, Blystad H, Lund A. Rabies in an Arctic fox on the Svalbard archipelago, Norway, January 2011. Euro Surveill. 2011;16(7):pii=19797. Available from: http://www. eurosurveillance.org/ViewArticle.aspx?Articleld=19797

4. Maclachlan NJ, Dubovi EJ, editors. Fenner's Veterinary Virology Fourth edition. Rhabdoniridae. San Diego: Academic Press; 2011.

5. Heymann DL, editor. Control of Communicable Diseases Manual. 19th edition. Washington: American Public Health Association. 2008.

6. Leung AK, Davies HD, Hon KL. Rabies: epidemiology, pathogenesis, and prophylaxis. Adv Ther. 2007;24(6):1340-7. 
7. Rabies vaccines: WHO position paper. Wkly Epidemiol Rec. 2010;85(32):309-20. Available from: http://www.who.int/ wer/2010/wer8532.pdf

8. Wertheim HF, Nguyen TQ, Nguyen KA, de Jong MD, Taylor WR, Le TV, et al. Furious rabies after an atypical exposure. PLoS Med. 2009;6(3):e44.

9. Geering WA, Penrith ML, Nyakahuma D. Animal Health Manual. Manual on procedures for disease eradication by stamping out. 2001. Food and Agriculture Organization of the United Nations. [Accessed 30 Sep 2011]. Available from: http://www.fao.org/ DOCREP/004/Yo66oE/Yo660Eoo.htm\#TOC 